\title{
Case Comment: Canada (Attorney General) v PHS Community Services Society
}

\author{
Rahool P. Agarwal ${ }^{\star}$
}

\section{Introduction}

In September of this year, the Supreme Court of Canada released its decision in Canada (Attorney General) v PHS Community Services Society ("PHS Community Services Society"). ${ }^{1}$ PHS Community Services Society is undoubtedly a landmark decision. Most importantly, the Court ordered the continued operation of Insite, North America's only supervised injection site, and a health program that has proven to be overwhelmingly effective in addressing addiction drug use in Vancouver's Downtown East Side (the "DTES"). But the decision is also critically important as part of the Supreme Court's body of constitutional jurisprudence. In this case comment, I review the Court's decision, and discuss three important issues raised by the Court's analysis: (a) the availability of ministerial discretion as an "antidote" for an otherwise unconstitutional law; (b) what insight the decision may provide with respect to the relationship between the Court and Parliament; and (c) PHS Community Services Society's utility as a precedent for future supervised injection sites.

\section{Background}

In the 1990s, concern began to mount about the drug-related health crisis in British Columbia, particularly in the DTES. In just six years, the number of annual deaths from drug overdoses in Vancouver increased exponentially, from
16 in 1987 to 200 in $1993 .{ }^{2}$ In 1996, the British Columbia Centre for Excellence in HIV/AIDS reported an HIV/AIDS epidemic in the DTES, and the following year an epidemic of Hepatitis C was reported. ${ }^{3}$ In September 1997, the Chief Medical Health Officer of the Vancouver Health Board declared a public health emergency in the DTES. ${ }^{4}$

Harm reduction strategies became a key part of the response to the DTES health crisis. In 1997, the Vancouver/Richmond Health Board adopted an HIV/AIDS action plan that included the creation of the Vancouver Area Network of Drug Users (VANDU) to provide peer outreach and support, as well as the establishment needle exchanges. ${ }^{5}$ In 1999, the Vancouver Coastal Health Authority issued a report recommending an integrated health approach that had as its focus harm reduction: expansion of primary care services, the development of creative interventions to address communicable disease, the development of a scheme of drug and alcohol services including harm reduction strategies, and improved access to stable housing. ${ }^{6}$

In April 2002, the Province transferred responsibility for adult alcohol and drug services to the regional health authorities, paving the way for the VCHA to integrate addiction treatment into the health care services it delivered in the DTES. ${ }^{7}$ In September 2002, VCHA pro- 
posed a new addictions plan that adopted harm reduction strategies, which included the establishment of a supervised injection site. ${ }^{8}$

In May 2003, VCHA submitted a proposal for a supervised injection site to Health Canada. ${ }^{9}$ For the proposed site to work, the operators of the site required an exemption from federal laws prohibiting the possession and trafficking of controlled substances. Section 56 of the Controlled Drugs and Substances Act ${ }^{10}$ (CDSA) provides the Minister of Health with the discretion to grant such exemptions. The proposal was approved and the exemption was granted on September 13, 2003, and Insite opened its doors on September 21, 2003. ${ }^{11}$ Insite is operated by PHS Community Services Society (PHS), a non-profit organization. ${ }^{12}$

The exemption expired on June 30, 2008, and was not renewed by the government. ${ }^{13} \mathrm{PHS}$, along with two individual Insite users, consequently commenced an action in the BC Supreme Court seeking relief, on constitutional grounds, that would keep Insite in operation. ${ }^{14}$

\section{Lower Court decisions}

PHS advanced two constitutional arguments: (1) as a provincial health undertaking, Insite is protected from the application of the CDSA under the division-of-powers doctrine of interjurisdictional immunity; and (2) the possession and trafficking provisions of the CDSA, insofar as they deny users meaningful access to Insite in the absence of a government exemption, violate section 7 of the Charter of Rights and Freedoms.

At trial, Justice Pitfield rejected the division of powers argument. He held that the operational conflict between Insite, as a provincial health care initiative, and the CDSA, enacted pursuant to the federal power over criminal law, was resolved in favour of the criminal law by application of the doctrine of paramountcy. ${ }^{15}$

However, Justice Pitfield accepted the argument that the possession and trafficking provisions of the CDSA infringed section 7 of the Charter and could not be justified under section $1{ }^{16} \mathrm{He}$ accordingly declared section 4(1) (prohibiting possession) and section 5(1) (prohibit- ing trafficking) to be of no force or effect, but suspended the declaration of constitutional invalidity for just over 12 months. ${ }^{17}$

Canada appealed Justice Pitfield's decision on the Charter to the BC Court of Appeal. PHS and the other claimants cross-appealed the dismissal of their division of powers claim. Justice Huddart, with Justice Rowles concurring, allowed the respondents' cross-appeal on the division of powers issue and declared sections 4(1) and 5(1) of the CDSA to be inapplicable to Insite by reason of the doctrine of interjurisdictional immunity. ${ }^{18}$ Although strictly unnecessary because of the finding on division of powers, Justice Rowles also considered the Charter issue and agreed with the trial judge that sections 4(1) and 5(1) of the CDSA violated section $7 .{ }^{19}$ Justice Huddart stated in her reasons that she agreed with Justice Rowles' Charter analysis. ${ }^{20}$

In dissent, Justice Smith found in favour of Canada on both the division of powers issue and the Charter issue, and would have allowed the appeal. ${ }^{21}$

Canada appealed the Court of Appeal's decision to the Supreme Court of Canada.

\section{The decision of the Supreme Court of Canada}

The Supreme Court of Canada, in a unanimous decision penned by Chief Justice McLachlin, dismissed Canada's appeal and ordered the federal Minister of Health to grant Insite an exemption under section 56 of the CDSA. ${ }^{22}$

On the division of powers issue, the Court held that interjurisdictional immunity did not apply to immunize Insite from application of the CDSA. ${ }^{23}$ The focus of the Court's decision was therefore section 7 of the Charter. Two elements of the Court's section 7 analysis are particularly important:

i. The Court held that the CDSA does not violate the Charter. The Court found that section 4(1) of CDSA, the prohibition on possession, infringed the liberty interests of Insite's staff and the life, liberty and security of the person interests of Insite's users, but that sec- 
tion 56 operated to render section 4(1) consistent with the principles of fundamental justice. The Minister is required to exercise his or her discretion under section 56 in a manner consistent with the Charter, which in the Court's view requires the Minister to prevent the CDSA from applying in manner that offends the principles of fundamental justice. ${ }^{24}$

ii. Nevertheless, the Court found that the Minister's refusal to renew/approve the exemption that expired on June 30, 2008 was contrary to section 7 . The resulting application of section 4(1) of the CDSA to Insite's staff and users was arbitrary and grossly disproportionate, and therefore contravened the principles of fundamental justice. ${ }^{25}$

The remedy fashioned by the Court is also significant. The Court made an order of mandamus and required the Minister to grant an exemption to Insite under section $56 .{ }^{26}$ The Court expressly considered making a declaration that the Minister erred and returning the matter to the Minister for reconsideration, as well as granting a constitutional exemption for Insite, but determined that both options were inadequate. ${ }^{27}$ In the Court's view, the mandamus order was the remedy that best enforced the respondents' Charter rights "in a responsive and effective manner." 28

\section{Commentary}

\section{(a) Ministerial discretion as an antidote for constitutional invalidity}

The heart of the Court's judgment is its analysis of section 7 of the Charter, and specifically its consideration of the principles of fundamental justice.

Both the trial court and the Court of Appeal found that section 4(1) of the CDSA impaired life, liberty and security of the person in a manner that offended the principles of fundamental justice, and therefore violated section 7. But the Supreme Court came to a different conclusion. The Court relied on the ministerial discretion contained in section 56 of the CDSA as an antidote to the deprivation caused by section 4(1). Because the minister's discretion, as state action, must be exercised in a manner that respects Charter rights, the Court reasoned that section 56 acts as a "safety valve" that prevents the CDSA from being applied in a manner that offends the principles of fundamental justice. ${ }^{29}$ In the Court's words, "[i]f there is a Charter problem, it lies not in the statute but in the Minister's exercise of the power the statute gives him to grant appropriate exemptions." ${ }^{30}$

This approach, however, is problematic. The discretion provided by section 56 is absolute and unfettered; it only provides that the Minister "may" grant an exemption if in his "opinion" an exemption is necessary for medical or scientific purposes or in the public interest. The legislation provides no further direction or constraints to guide the Minister in granting exemptions. There is no mention of an evidentiary threshold, a standard to meet, or factors for the Minister to consider.

The Court takes the view that this is sufficient because the Minister is constitutionally constrained-his decisions cannot violate the Charter. But without adequate legislative or judicial direction, there is a significant risk that the discretion could be exercised improperly. The consequence is that applicants seeking an exemption under section 56 have no real certainty with respect to the protection of their Charter rights. In the face of a refusal to grant an exemption, the only option is to commence a court action or an application for judicial review to attempt to enforce the Charter. Instead of a legislative scheme that protects Charter rights from the start, claimants will have to resort to the courts every time they feel the Minister has acted unconstitutionally.

This unpredictability leaves the legislation potentially in breach of section 7 . The constitutional principle of vagueness, which is a principle of fundamental justice, entitles individuals not to be deprived of life, liberty or security of person by laws that are vague or unintelligible. A completely discretionary power as the only "safety valve" preventing a section 7 violation does not meet that standard. It cannot be that a law is constitutionally sound if it could be applied correctly-individuals are surely entitled to greater certainty when their rights are at stake. 
In fairness, the Court does provide some commentary on the proper exercise of the Minister's discretion:

The dual purposes of the CDSA-public health and public safety-provide some guidance for the Minister. Where the Minister is considering an application for an exemption for a supervised injection facility, he or she will aim to strike the appropriate balance between public health and public safety goals. Where, as here, the evidence indicates that a supervised injection site will decrease the risk of death and disease, and there is little or no evidence that it will have a negative impact on public safety, the Minister should generally grant an exemption.

...The factors considered in making the decision on an exemption must include evidence, if any, on the impact of such a facility on crime rates, the local conditions indicating a need for such a supervised injection site, the regulatory structure in place to support the facility, the resources available to support its maintenance, and expressions of community support or opposition. ${ }^{31}$

These comments are certainly helpful, but are ultimately too broad to provide the level of certainty required by the Charter. An applicant under section 56 of the CDSA does not have sufficient clarity as to how the discretion will be applied. Moreover, these statements are couched by the very clear pronouncements of the Court that the Minister's discretion is unfettered: for example, the Court states that "the Minister should not be precluded from withdrawing an exemption to Insite should changed circumstances at Insite so require," 32 and also that its decision "does not fetter the Minister's discretion with respect to future applications for exemptions, whether for other premises, or for Insite." ${ }^{33}$

By comparison, PHS Community Services Society is not Suresh $v$ Canada (Minister of Citizenship and Immigration) ${ }^{34}$ ("Suresh"). Suresh considered the constitutionality of a discretionary ministerial decision to deport an individual to face torture. A unanimous Court upheld the Minister's discretionary power as constitutional, but also directed that the discretion should almost never be used to deport an individual to face torture. ${ }^{35}$ The guidance provided by the Court in PHS Community Services Society does not come close to the clear direction-and effective constraint on ministerial discretiongiven by the Court in Suresh.

Notably, this very same issue was directly addressed over ten years ago by the Ontario Court of Appeal in $R v$ Parker $^{36}$ ("Parker"). Parker dealt with the constitutionality of section 4(1) of the CDSA as a blanket prohibition on marijuana. The accused, who suffered from epilepsy, argued that he required the use of marijuana for medicinal purposes. A unanimous court held that section 4(1), because it prohibited access to marijuana, impaired the accused's rights to liberty and security of the person. The Crown, however, argued that the CDSA was nevertheless constitutionally valid because of section 56 , for the same reason as relied upon by the Supreme Court in PHS Community Services Society - the Minister, in exercising his discretion, was required to act in a manner consistent with the Charter. ${ }^{37}$

The Crown's argument was rejected by the Court:

In view of the lack of an adequate legislated standard for medical necessity and the vesting of an unfettered discretion in the Minister, the deprivation of Parker's right to security of the person does not accord with the principles of fundamental justice.

In effect, whether or not Parker will be deprived of his security of the person is entirely dependent upon the exercise of ministerial discretion. While this may be a sufficient legislative scheme for regulating access to marihuana for scientific purposes, it does not accord with fundamental justice where security of the person is at stake. ${ }^{19}$

...The court cannot delegate to anyone, including the Minister, the avoidance of a violation of Parker's rights. Section 56 fails to answer Parker's case because it puts an unfettered discretion in the hands of the Minister to determine what is in the best interests of Parker and other persons like him and leaves it to the Minister to avoid a violation of the patient's security of the person. ${ }^{38}$ 
In the trial judgment in PHS Community Services Society, the Court adopted the Ontario Court of Appeal's analysis and found that section 56 could not be relied upon as cure to an infringement caused by section 4(1). ${ }^{39}$ The Supreme Court of Canada, however, gives Parker short shrift:

I note that this case is different from Parker, where the Ontario Court of Appeal held that the general prohibition on possession of marihuana was not saved by the availability of an exemption for possession for medical purposes under s. 56. No decision of the Minister was at stake in Parker, and the Court's conclusion rested on findings of the trial judge that, at that time, "the availability of the exemption was illusory" (para. 174). ${ }^{40}$

The Supreme Court mischaracterizes Parker. The Ontario Court of Appeal's decision did not rest on the finding that the availability of an exemption was "illusory." Rather, the Court of Appeal was unconvinced that unfettered discretion in the hands of the Minister could withstand Charter scrutiny; whether an exemption for medicinal marijuana was likely to be granted was not a central consideration for the court.

In any event, and more importantly, the relevance of the availability of an exemption under section 56 at any given time to the constitutionality of the CDSA is highly questionable. Either the legislation is constitutionally valid, or it is not-the political climate in favour or against an exemption should not be determinative of a law's constitutionality. ${ }^{41}$

\section{(b) The relationship between the Supreme Court and Parliament}

The analytical approach adopted by the Court may also provide some insight into the Court's relationship with Parliament.

The Court's recent constitutional jurisprudence demonstrates a highly deferential posture in relation to state action and legislation-examples include the Court's decisions in $\mathrm{Khadr}^{42}$ Cunningham, ${ }^{43}$ Fraser, ${ }^{44}$ Toronto Star Newspapers, ${ }^{45}$ and Withler. ${ }^{46}$ For many commentators, PHS Community Services Society represents a divergence from that trend. One prominent le- gal journalist wrote that PHS Community Services Society threatens the "peace between judges and legislators." ${ }^{37}$

Certainly, by its outcome, PHS Community Services Society sends the strong message that government, despite its policymaking role, is still ultimately subject to the constitution. But upon closer inspection, PHS Community Services Society appears to be more consistent with governmental deference than a striking departure towards judicial activism.

The remedy chosen by the Supreme Courtto keep the CDSA intact and instead order the minister to act-was not the only available remedy and in fact, short of granting the appeal, the least invasive. The Court could have adopted the Court of Appeal's approach in Parker and granted a suspended declaration of constitutional invalidity, allowing Parliament to consider the issues and propose legislation that would conform with the Charter. That was the also the remedy ordered by the trial judge. Instead, the Supreme Court crafted a remedy that encroached very little on Parliament: the CDSA remains untouched, and the minister retains virtually unfettered discretion over section 56 applications (as stated above, the Court emphasizes at several points in its reasons that the scope of the Minister's discretion is not affected by the decision). Rather than following existing jurisprudence, the Court manufactured a wholly new approach, with the result being the same immediate outcome-Insite's continued operation-but with a greater degree of deference to Parliament.

\section{(c) PHS Community Services Society is not a precedent for the establishment of other safe injection sites}

For advocates of harm reduction, it is certainly tempting to read PHS Community Services Society as a potential blueprint for sites like Insite to be established in other parts of the country. Groups in Montreal and Quebec City are reportedly in the process of making applications for supervised injection sites to the Minister of Health. However, a more critical reading of the decision reveals that it will likely be of limited 
utility outside of Insite and the DTES.

The decision's limited application stems from its firm grounding in evidence specific to Insite. The basis for the Court's conclusion that denial to Insite caused a deprivation of life, liberty and security of the person was the trial judge's findings that many of the health risks of injection drug use are caused by unsanitary practices and equipment and that "the risk of morbidity and mortality associated with addiction and injection is ameliorated by injection in the presence of qualified health professionals." 48 Similarly, the Court's conclusion that the Minister's refusal to approve the exemption was contrary to the principles of fundamental justice was based on several key factual findings: (1) traditional criminal law prohibitions have done little to reduce drug use in the DTES; (2) health risks to injection drug users are reduced when they inject under the supervision of a health professional; and (3) Insite did not contribute to increased crime rates, rates of public injection or relapse. ${ }^{49}$

The Court emphasized that the decision was based strictly on the evidence and that its scope should be regarded as limited:

\begin{abstract}
The conclusion that the Minister has not exercised his discretion in accordance with the Charter in this case, is not a licence for injection drug users to possess drugs wherever and whenever they wish. Nor is it an invitation for anyone who so chooses to open a facility for drug use under the banner of a "safe injection facility." The result in this case rests on the trial judge's conclusions that Insite is effective in reducing the risk of death and disease and has had no negative impact on the legitimate criminal law objectives of the federal government. ${ }^{50}$
\end{abstract}

The Court's expressly narrow analysis poses a significant problem for those intent on using the decision as a precedent for establishing a safe injection site, for two reasons.

First, the key factual findings relied on by the Court, i.e. the reduction in the risk of death by overdose and the transmission of infectious diseases, relates to outcomes caused by Insite during its operation. A new applicant for a safe injection site will have no such evidence to rely upon, because there is no existing supervised injection site to which to make reference. The Court makes clear that the Minister's decision to refuse approval was contrary to the Charter in 2008 because the information regarding Insite's health successes was available the Minister at that time; Insite had been in operation for five years and achieved reductions in death and disease associated with injection drug use. Unless a site is approved, put into operation, and then the approval is removed or refused, the factual matrix that lead to the evidence relied upon by the Court will not exist. Decisions by the Minister under section 56 must be consistent with the Charter, but if the threshold for Charter compliance is approval of a program that ameliorates death and disease, new applications are doomed to fail because there is simply no way to prove that a new site will have the same level of success.

Second, even considering only the evidence that was available at the time of Insite's initial approval as a reference point, new applicants are still in a very difficult position. The Court's approach suggests that the Minister's decision was unconstitutional in part because it failed to have regard for the specific health situation in the DTES. But the health crisis in the DTES that lead to the approval and creation of Insite in 2002 was unprecedented. The concentration of addiction, injection drug use and overall poor health conditions in the DTES was, and remains, unique when compared to any other community in the country. If the DTES is the standard for the approval of a safe injection site, very few, if any, applications will meet the standard.

The likelihood for refusal of an application under section 56 in these circumstances is even greater given that the government expressly opposes supervised injection as a policy choice and the Minister retains full discretion over the approval process. The Minister will surely be inclined to imposing a high standard for future applications under section 56, and the decision can certainly be interpreted to support that approach. 


\section{Notes}

* Rahool P. Agarwal is lawyer in the litigation group at Norton Rose OR LLP in Toronto. He acted as counsel to a coalition of nurses' associations that intervened before the Supreme Court of Canada in this case. Mr. Agarwal would like to thank Daniel Pearlman, student-at-law, Norton Rose OR LLP, for his assistance in preparing this article.

1 Canada (Attorney General) v PHS Community Services Society, 2011 SCC 44, [2011] SCJ no 44 (QL) [PHS (SCC)].

$2 \quad$ Ibid at para 11.

3 Ibid.

4 PHS Community Services Society $v$ Canada (Attorney General), 2008 BCSC 661 at para 26, 293 DLR (4th) 392 [PHS (Trial)].

$5 \quad$ PHS (SCC), supra note 1 at para 13.

$6 \quad$ Ibid.

7 PHS (SCC), supra note 1 at para 14.

$8 \quad$ Ibid.

$9 \quad$ Ibid at para 16.

10 Controlled Drugs and Substance Act, SC 1996, c 19, s 56 [CDSA]. Section 56 of the CDSA reads: "The Minister may, on such terms and conditions as the Minister deems necessary, exempt any person or class of persons or any controlled substance or precursor or any class thereof from the application of all or any of the provisions of this Act or the regulations if, in the opinion of the Minister, the exemption is necessary for a medical or scientific purpose or is otherwise in the public interest."

11 PHS (SCC), supra note 1 at paras 16-17.

12 Ibid at para 21.

13 Ibid at paras 121-122.

14 PHS's action was heard together with a claim by VANDU, wherein VANDU sought a declaration that the conduct of Insite's staff in the ordinary course of business did not amount to an offence at law, thereby obviating the need for an exemption for staff under section 56 of the CDSA. Both actions were dealt with together at each level of court.

15 PHS (Trial), supra note 4 at paras 117-121.

16 Ibid at paras 140-153.

17 Ibid at paras 158-159.

18 PHS Community Services Society v Canada (Attorney General), 2010 BCCA 15 at para 193, 314 DLR (4th) 209, Huddart J [PHS (Court of Appeal)].

19 Ibid at para 77, Rowles J.

20 Ibid at para 199, Huddart J.

21 Ibid at paras 306-309, Smith J.
PHS (SCC), supra note 1 at para 3.

Ibid at paras 57-70.

Ibid at paras $107-115$.

Ibid at paras 126-136.

Ibid at para 150 .

Ibid at paras 146-149.

Ibid at para 142 .

Ibid at para 113 .

Ibid at para 114 .

Ibid at para 152-153.

Ibid at para 149 .

Ibid at para 151.

Suresh $v$ Canada (Minister of Citizenship and Immigration), 2002 SCC 1, [2002] 1 SCR 3 [Suresh]. Ibid at paras 77-78.

$R v$ Parker, (2000), 49 OR (3d) 481, 188 DLR (4th) 385 [Parker].

Ibid at para 175.

Parker, supra note 36 at paras 184-185, 187.

PHS (Trial), supra note 4 at paras 154-155.

PHS (SCC), supra note 1 at para 118.

It is worth noting that in PHS Community

Services Society, the availability of an exemption

was in fact less than illusory: it was non-existent, because the Minister expressly refused to provide an exemption.

2 Canada (Prime Minister) v Khadr, 2010 SCC 3, [2010] 1 SCR 44. The Court declared that Canada's investigation of Omar Khadr had violated his section 7 rights, but did not order his return to Canada and instead left the government with the discretion to determine how to respond to the Court's ruling.

Alberta (Aboriginal Affairs and Northern Development) v Cunningham, 2011 SCC 37, [2011] SCJ no 37 (QL). The Court overturned the Alberta Court of Appeal's decision and held that legislation that excluded status Indians from becoming formal members of any Métis settlements did not infringe the Charter.

44 Ontario (Attorney General) v Fraser, 2011 SCC 20, [2011] 2 SCR 3. The Court overturned the Ontario Court of Appeal and found that legislation excluding farm workers from the Labour Relations Act did not infringe the Charter. Toronto Star Newspapers Ltd v Canada, 2010 SCC 21, [2010] 1 SCR 721. The Court held that a provision of the Criminal Code that imposed "a mandatory ban on evidence and information produced, and representations made, at a bail hearing and to any reasons given for the order," infringed the freedom of expression but was justified under section 1 of the Charter. Withler v Canada (Attorney General), 2011 SCC 12, [2011] 1 SCR 396. The Court dismissed the 
appellants' argument that the Public Service Superannuation Act and the Canadian Forces Superannuation Act were discriminatory because they provided for a reduction in certain benefits on the basis of increasing age.

47 Kirk Makin, "Landmark Insite decision threatens peace between judges and legislators," The Globe and Mail (11 October 2011).

$48 \quad$ PHS (SCC), supra note 1 at para 93.

49 Ibid at para 131.

50 Ibid at para 140 (emphasis added). 